Hagit Gill · Ilan Paperna

\title{
Leucocytozoonosis in the Israeli sparrow, Passer domesticus biblicus Hartert 1904
}

Published online: 20 September 2005

(C) Springer-Verlag 2005

\section{Parasitol Res (2005) 96:373-377}

In the online PDF and the print version, Figs. 5-8 are duplicates of Figs. 1-4. The correct Figs. 5-8 are given here.

The online version of the original article can be found at http:// dx.doi.org/10.1007/s00436-005-1352-4

H. Gill · I. Paperna $(\bowtie)$

Department of Animal Sciences, Faculty of Agricultural,

Food and Environmental Quality Sciences, The Hebrew University of Jerusalem, Rehovot, 76100, Israel

E-mail: paperna@agri.huji.ac.il

Tel.: + 972-8-9489945

Fax: + 972-8-9465763 
Figs. 5-8 Kidney histology of Leucocytozoon-infected sparrow; MHE, same scale bar $15 \mu \mathrm{m}$

Fig. 5 Congestion of blood vessels by gametocytes $(\mathrm{C})$ with gradual vacuolar degeneration of the tubular and interstitial renal tissue $(\mathrm{V})$. One tubule contains merogonic stages $(\mathrm{Z})$ Fig. 6 Assembly of degenerated and necrotic kidney tubules (arrows); meronts present in the intact tubular tissue (Z)

Fig. 7 Longitudinal view of necrotized tubule (D), adjoining congested blood vessel (C); cells of the kidney tubule contain Leucocytozoon young meronts (arrows)

Fig. 8 Leucocytozoon

gametocytes nested in the blood vessels (fine arrows) of the glomerulus (bold arrow)

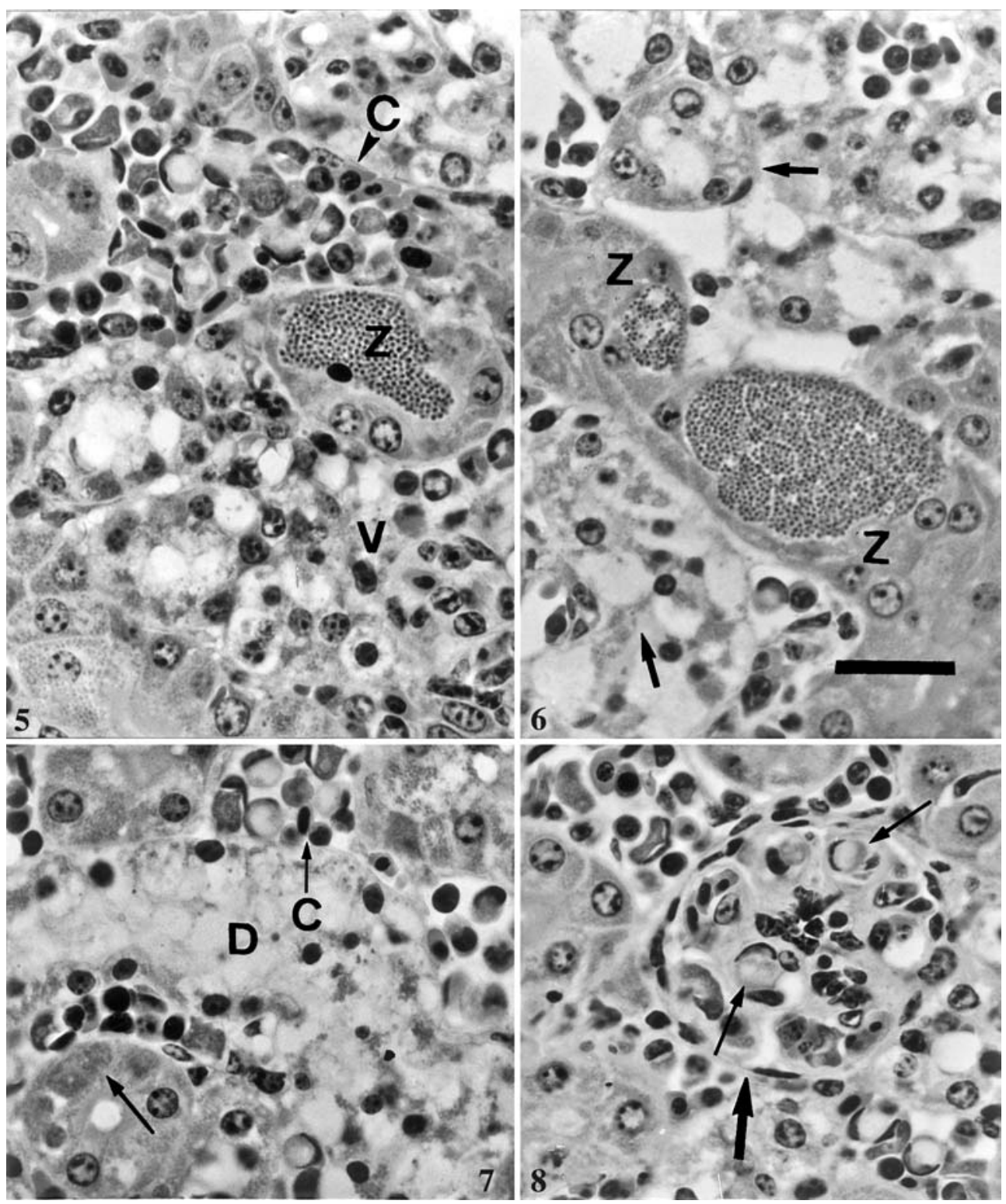

